\author{
Renata Gałaj-Dempniak \\ (Univesity of Szczecin, Poland) \\ https://orcid.org/0000-0001-9006-6633 \\ E-mail: renata.galaj-dempniak@usz.edu.pl
}

\title{
The History of Poland in the Service of State Promotion: an Example of Activities in Japan
}

Historia Polski w służbie promocji państwa: na przykładzie działań w Japonii

\begin{abstract}
History is strongly linked to the country and its citizens. It identifies the nation and the country, it helps to preserve the identity by reminding the people of their legacy. That is why it is a perfect means of building a country's brand and evoking associations with its location and society. Poland is constantly searching for new markets for its products, even in countries in which it is barely present. One of the countries whose market Poland is trying to get into is Japan, a country whose citizens do not know much about Poland. In order to facilitate the relations between these two countries, the Polish government decided to launch an information campaign about Poland's past and present, its possibilities, its significance in the international arena, and its people. Considering the character of Japanese culture a comic has been chosen to be the adequate medium.
\end{abstract}

Key words: Manga, Japan, Poland, promotion

\begin{tabular}{|c|c|c|c|c|}
\hline \multicolumn{5}{|c|}{ PUBLICATION INFO } \\
\hline I INERST & UMCS & * & $\begin{array}{l}\text { e-ISSN: } 2449-8467 \\
\text { ISSN: } 2082-6060\end{array}$ & OPEN@ACCESS \\
\hline \multicolumn{5}{|c|}{$\begin{array}{l}\text { THE AUTHOR'S ADDRESS: Renata Gałaj-Dempniak, the Historical Institute of the University of Szczecin, 71-79 } \\
\text { Krakowska Street, Szczecin 71-017, Poland }\end{array}$} \\
\hline \multicolumn{5}{|c|}{ SOURCE OF FUNDING: Statutory Research of the Historical Institute of the University of Szczecin } \\
\hline \multicolumn{2}{|c|}{$\begin{array}{l}\text { SUBMITTED: } \\
\text { 2019.10.06 }\end{array}$} & $\begin{array}{l}\text { ACCEPTED: } \\
2020.11 .26\end{array}$ & $\begin{array}{l}\text { PUBLISHED ONLINE: } \\
\text { 2021.06.30 }\end{array}$ & (c) \\
\hline \multicolumn{3}{|c|}{$\begin{array}{l}\text { WEBSITE OF THE JOURNAL: } \\
\text { https://journals.umcs.pl/rh }\end{array}$} & $\begin{array}{l}\text { EDITORIAL } \\
\text { COMMITTEE E-mail: } \\
\text { reshistorica@umcs.pl }\end{array}$ & Crossref dol \\
\hline
\end{tabular}




\section{STRESZCZENIE}

Historia jest silnie powiązana z krajem i jego obywatelami. Identyfikuje naród i kraj, pomaga zachować tożsamość, przypominając ludziom o ich dziedzictwie. Dlatego jest doskonałym sposobem budowania marki kraju, budząc skojarzenia z jego lokalizacją i społeczeństwem. Polska nieustannie poszukuje nowych rynków dla swoich produktów, nawet w krajach, w których jest ledwo obecna. Jednym z krajów, na którego rynek stara się wejść Polska, jest Japonia, kraj, którego obywatele niewiele wiedzą o Polsce. Aby ułatwić relacje między tymi dwoma krajami, polski rząd postanowił rozpocząć kampanię informacyjną o przeszłości i teraźniejszości Polski, jej możliwościach, znaczeniu na arenie międzynarodowej i jej mieszkańcach. Biorąc pod uwagę charakter japońskiej kultury, komiks został wybrany jako najbardziej odpowiednie medium.

Słowa kluczowe: Manga, Japonia, Polska, promocja

In the recent years, Polish-Japanese relations have improved for Poland. For a long time, Japanese culture has had its advocates in our country and has been systematically promoted ${ }^{1}$. The situation of Polish culture in Japan has been similar. The Polish Institute in Tokyo and the Embassy of the Republic of Poland carry out activities aimed at popularizing the culture and history of our country. These activities are to stimulate the association of the term "Poland" with specific symbols, flavours, information, curiosities, so that the potential tourists or investors will not omit the Polish offer, because it will evoke desirable emotions and associations. An essential and important change has also become the placement of Japanese investments in Poland as their target country ${ }^{2}$. It is true that

1 Muzeum Sztuki i Techniki Japońskiej Manggha w Krakowie, Szkoła Języka Japońskiego, Japonia-online, http://japonia-online.pl/article/559 [dostęp: 10 V 2016]; In Krakow, there is an institution that educates tea ceremony apprentices, promotes/instills associations such as Senshinkai, and organizes exchanges between Polish and Japanese schools flourish, http://japonia-online.pl/article/559 [dostęp: 10 V 2016]; Ambasada Japonii w Polsce, http://www.pl.emb-japan.go.jp/kultura/20151215.html Facebook, http://www. lazienki-krolewskie.pl/pl/aktualnosci/ksiezna-takamado-z-wizyta-w-lazienkach-krolewskich [dostęp: 10 V 2016].

2 Building Framework for Strategic Partnership for Freedom, Growth and Solidarity, http:// www.mofa.go.jp/erp/c_see/pl/page4e_000197.html [dostęp: 10 V 2016]; Porozumienie w sprawie TPP oraz drugi etap abenomiki - polityki gospodarczej premiera Shinzo Abe, Makoto Yamanaka, Ambasador Japonii w Polsce, http://www.pl.emb-japan.go.jp/ambasada/ documents/letter13.html [dostęp: 27 VI 2016]; AJ, http://www.pl.emb-japan.go.jp/relations/20151211.htm [dostęp: 27 VI 2016]; Polska-brama japońskich inwestycji, Invest in Poland, http://www.paiz.gov.pl/20150227/polska_brama_japonskich_inwestycji, [dostęp: 27 VI 
the Japanese themselves claim that whoever wanted to invest in Poland has already done so, but there is still plenty of space for new foreign investments. The search for new markets is very important for Poland, therefore our country needs to carry out the most effective promotional activities, and one of them is history that leads to getting to know the partner. History understood as a process taking place not only in the political and military area but also culture and even cuisine. The Polish government has undertaken a difficult process of building a state brand whose important elements are associations with graphic signs, symbolism related to Poland, recognizable places, people, flavours. This task is all the more difficult, the poorer relationships have been between the partners.

The Japanese do not know much about Poland, and getting them informed is not easy. This is best known to the employees of the Polish Chamber of Tourism and investors from Poland who have entered the difficult Japanese market. Research indicates that the Japanese prefer brands, goods, and manufacturers they know, that command confidence. The Japanese have not heard much about Poland so far, which is why the Polish government has been presenting them with a package of Polish history and, not very numerous, historical relations between the two countries for several years now.

In Japan, Polish producers, including food manufacturers, are more and more frequently attending trade fairs. For years, Polish music, theatre and film art have been promoted on the occasion of round anniversaries relating to the life of composers, musicians, writers, film makers as well as painters, sculptors and graphic artists. But the best way to reach the addressee seems to be the message traditionally present in the society of this country, which is part of the culture of Japan. The Japanese, regardless of age, prefer manga as a form of learning about the world and culture, providing them with entertainment and even education. The current development of manga and research on its readers show that the Japanese and other Asians seek manga and anime for not only knowledge and entertainment, but also - what is most disturbing - role models and behavioral patterns.

From this perspective, using comics by the Polish authorities as sources of education and information about Poland seems to be justified in every respect. Both countries have maintained relations on many levels for a long time, however, due to the distance of markets and borders

2016]; Prezydent $i$ polski biznes z wizyta w Japonii, Invest in Poland, http://www.paiz.gov. pl/20150226/prezydent_i_polski_biznes_z_wizyta_w_japonii [dostęp: 26 II 2016]; Polskojapońskie wiadomości gospodarcze, Jetro Poland, https://www.jetro.go.jp/poland/wiadomosci/gospodarcze.html [dostęp: 26 II 2016]. 
they have been limited in scope ${ }^{3}$. Many citizens of both countries are not aware that such ties existed at all. Thanks to the comic book, the history of these relations has come to light again, and the research conducted by the Polish Embassy in Tokyo indicates that many Japanese, especially young people, gain knowledge about Poland provided by means of this form of communication. Many countries have recently been using the comic in promotional activities abroad as it is a medium that reaches all age categories of readers. The Polish authorities have already attempted to promote knowledge about our country with the help of a comic (on Fryderyk Chopin's music: The Anthology of "Chopin New Romantic") in $2010^{4}$. The comic book was supposed to be part of the promotional program of Polish culture in the Chopin Year, and it was financed by, among others, Polish Embassy in Berlin and the Ministry of Foreign Affairs. However, the language of one of the comic books included in the mentioned anthology aroused controversy, triggered a discussion about the knowledge of comic as a communication medium and language culture $^{5}$. Some people argued that the government cannot promote a vulgar language, even if it forms part of a specific pop culture. Despite the bad

3 Ten Hibakusha - a Japanese, who survived the atomic bomb explosion in Hiroshima and Nagasaki in 1945, and 800 other participants of the cruise visited Gdansk in June 2010. They promoted peace, human rights, sustainable development and environmental protection. The participants of the cruise visited also Krakow and Oświęcim. Gdańsk has been included in the "Presidential Peace Program" since 2007, whose initiators are the presidents of Hiroshima and Nagasaki, http://www.tvp.pl/gdansk/aktualnosci/spoleczne/ statek-pokoju-przyplynal-do-gdanska/1882340 [dostęp: 10 IX 2015]; R. Gałaj-Dempniak, Obraz stosunków polsko-japońskich w prasie japońskiej i na japońskich stronach internetowych, w: Dylematy polityki zagranicznej Polski na poczatku XXI w., red. K. Czornik, M. Lakomy, M. Stolarczyk, Katowice 2014, s. 586-606; R. Gałaj-Dempniak, M. Pozorski, Stosunki polsko-japońskie w latach 2014-2016, w: Stosunki Polski z mocarstwami w drugiej dekadzie XXI wieku, red. K. Czornik, M. Lakomy, M. Stolarczyk, Katowice 2016, s. 304-338.

4 The authors of the collection of comics devoted to Chopii were recognized Polish and German creators of this genre: Jakub Rebelka, Marcus „Mawil” Witzel, Jacek Frąś, Sascha Hommer, Krzysztof Ostrowski, Agata „Endo” Nowicka, Andreas Michale, Patryk Mogilnicki, Jan-Frederik Bandel, Monika Powalisz, Grzegorz Janusz. Vulgarisms in one of the comics caused protests and the edition had to be withdrawn from the market. KLe, RC, Wulgarny komiks o Chopinie to "przypadek”, Onet- wiadomości, http://wiadomosci.onet.pl/ kraj/wulgarny-komiks-o-chopinie-to-przypadek/b2xxr [dostęp: 22 II 2011]; T. Sikora, Komiks o Chopinie na przemiat, czyli kto "nie skumat", Niemcy-online, http://www.niemcy-online.pl/inne/audio-video/komiks-o-chopinie-na-przemial-czyli-kto-nie-skumal-558 [dostęp: 24 II 2011].

5 MSZ: Komiks o Chopinie musi zostać zniszczony, http://wiadomosci.gazeta.pl/wiadomosci /1,114873,9149028,MSZ_Komiks_o_Chopinie_musi_zostac_zniszczony.html [dostęp: 22 II 2011]. 
experience, this promotion method has not been abandoned. The author of the comics issued with the co-financing of the Polish Embassy in Tokyo is Rafał Gosieniecki ${ }^{6}$. These comics form an integral part of the embassy's news bulletin, which the institution has been publishing in Japanese in cooperation with the Polish Institute and WPHI in Tokyo since September 2012. The same comics have also appeared in the English version. On the website of the Polish embassy in Tokyo one can find a link to the published comics, which familiarize not only the Japanese but also other visitors with the history and civilizational achievements of our country. One of the sections of the bulletin: "Mini Glossary" is co-created by students of Polish Studies at the Tokyo University of Foreign Studies (TUFS), who present in each issue of the bulletin one Polish word - their association with Poland ${ }^{7}$. This is also a way of building knowledge and the brand, giving the opportunity to follow the processes of growing "Poland" into the consciousness of the society of another country.

The comic issued as part of the promotion of Poland is to educate and form bonds, develop understanding, positive associations and feelings. It is also to recollect common moments in history when the citizens of both countries selflessly provided assistance to each other in difficult moments ${ }^{8}$. The latest manga on Polish "Siberian Children” saved by the Polish Rescue Committee of Children of the Far East and the Japanese Red Cross in the 1920's was published in Japanese ${ }^{9}$. It was issued in

6 A graduate of the Graphic Department of the Academy of Fine Arts in Gdańsk. He collaborated with the "Produkt" magazine and the "Mandragora” publishing house. He made illustrations for international advertising agencies and magazines („Marie Claire”, "Bravo Girl”). In 2006, he participated in the international comic project of the Asia-Europe Foundation. He has exhibited his works in Poland, France, Macedonia, the Czech Republic, Bangladesh, Singapore and Japan. He was a scholarship holder of the government of Japan twice, Gildia.pl, http://www.komiks.gildia.pl/tworcy/rafal_gosieniecki [dostęp: 6 VI 2016]; Ł. Chmielewski, Komiks promuje Polskę w Japonii, Culture.pl, http://culture.pl/pl/tag/rafal-gosieniecki [dostęp: 6 VI 2014].

7 Komiks Fryderyk Chopin w Tokio, http://www.tokio.msz.gov.pl/pl/aktualnosci/komiks_fryderyk_chopin_w_tokio [dostęp: 6 VI 2016].

8 Pomoc dla Japonii, news, http://www.news365.pl/index.php?option=com_content\&vi ew=article\&id=175:pomoc-dla-japonii\&catid=43:ogoszenia\&Itemid=37 [dostęp: 6 VI 2016]; The aid was organized by the Polish Humanitarian Organization, Niezwykty sukces "Solidarnych z Japoniq", Polskie Radio, http://www.polskieradio.pl/9/201/Artykul/562720,Niezwykly-sukces-Solidarnych-z-Japonia, [dostęp: 6 VI 2016]; Ambasada Japonii w Polsce, http://www.pl.emb-japan.go.jp/jishin/kumamoto-gienkin.htm [dostęp: 6 VI 2016]; Caritas dla Japonii-pomoc ofiarom trzessienia ziemi, Caritas Polska, http://www.caritas.pl/caritas-dla-japonii/ [dostęp: 18 IV 2016].

9 Poplar, http://www.poplar.co.jp/shop/shosai.php?shosekicode=60360020 [dostęp: 6 VI 2016]. 
the Japanese educational publishing house Poplar ${ }^{10}$. The Embassy of the Republic of Poland in Tokyo participated to the costs of publishing and elaborating. The book has 127 pages written by Kozo Kaku ${ }^{11}$ and Toshiki Mizutani ${ }^{12}$. Both authors have been working on comics popularizing the history of Japan for many years. The book was illustrated by Ryo Kitakami. Japan has a difficult and unregulated past with Russia (the issue of the Kurul islands). Therefore, the issue of a difficult Polish-Russian or earlier Polish-Soviet past may be moreso interesting for the readers. Manga tells the story of the creation in Vladivostok the Polish Rescue Committee of Children of the Far East by Polish diaspora activists, originated from the exiles to Siberia and their descendants ${ }^{13}$. Its main goal was to save the Polish exiles' children from Siberia. The work of the Committee was led by Anna Bielkiewicz. Her closest collaborator was Dr. Józef Jakóbkiewicz. The Committee, with the support of the Japanese Red Cross, the Ministry of Foreign Affairs of Japan and the members of Polish diaspora in America, in 1919-1922, deported 877 children and 93 adults from the home war-torn and revolutionary Russia. Most of them were transported by ships of the Japanese Merchant Marine, through Japan, the USA and England, to Poland. In Japan, the Polish children found not only a temporary shelter but also tender care. One of the institutions which helped them was the current Fukudenkai Social Welfare Centre in Tokyo's Hiroo district. Thanks to the memory of these events the Centre has still special bonds with the Polish Embassy in Tokyo. It seems that not only the majority of Japanese society but also most of Poles have not heard about it before.

Comics published with the participation of the Polish Embassy fall into one of the three categories: special issues informing about important events in international relations from the Polish point of view, great Poles, symbols and legends of Polish cities.

The first category includes two comics concerning the functioning of Poland in NATO and Poland's relations with its closest neighbor-Germany. The comic book on Poland in NATO covers the period from the Polish accession to the organization to the NATO summit, which took place in Warsaw on July 8-9, 2016. The reader learns that after World War II Poland was under the influence of communists and in the years 1955-1991

\footnotetext{
10 It was established as a publishing house, specialising in books for children, over 65 years ago. With time, it introduced publishing books for all age groups, with a wide range of themes. Annually, it publishes about 500 titles.

11 An author of comics devoted to the history of Japan.

12 An author of comics popularizing the history of Japan.

13 16th September 1919.
} 
it was part of the Warsaw Pact, dominated by the USSR. This information is cast on the outline of Europe's map, with clearly marked state borders. The second picture shows General Secretary Manfred Wörner, who after the political transformation in Poland in 1989, visited our country in 1992 and announced that the Polish state had an open door to NATO. The next milestone recorded in the comic-book pictures was Poland's accession to the organizational structures, as shown by the drawing of a Polish soldier brothering himself with a NATO soldier. Entering NATO structures took place in several stages. The first was the accession of the country in 1994 to the "Partnership for Peace" program. The second started during the NATO summit in Madrid in 1997, when the decision was made to admit Poland, Hungary and the Czech Republic to the organization. In January 1999, NATO Secretary General Javier Solana designated 12th March that year as the day of admission of new members into the organization. It can be said that they showed in a nutshell the path leading the Polish state to the organization, in which as an active member Poland crowned its activity by organizing the prestigious NATO summit. This undoubtedly demonstrates the aspirations of the country's authorities and its economic potential allowing them to engage in costly peace-keeping tasks in the world. It shows the path of political systemic transformations leading to building new international relations. As for the content and symbolism used in the comic, it is difficult to have any reservations.

The story of the Polish-German treaty on good-neighborliness begins with symbolism, which in Poland is automatically associated with a citizen of Poland or Germany. Against the background of the state flags, the author placed two symbolic images of soldiers, unfortunately from different eras. Germany is represented by a knight in the medieval Teutonic armament, Poland by a hussar. Perhaps one should not attach so much importance to details, but these two characters could probably meet only in the field of demonstration of reconstruction groups. Admittedly, the comic is governed by its own laws, but for a non-historian the time perspective created by means of graphics becomes misleading. The author had good intentions, but if, in principle, the Polish side promotes the history of its own country, he should have shown greater concern for details. Under the graphics in the cartouche there is an inscription informing that both countries have a long history, but their mutual relations have not always been as friendly, open and easy as today. Against the background of the letter and vision of the mass celebrated together, one of the most famous sentences spoken at the address of the Germans by the Polish Church is depicted: "We forgive and ask for forgiveness". From the cartouche, one can also learn that after the Second World War, in 1965, the Polish Episcopate sent a letter to the German bishops regarding 
reconciliation and mutual forgiveness which should prevail between societies and both states. These words are taken out of the context of the history of the Polish church, the author does not mention the price that the Polish clergy came to pay for this gesture. They serve, however, to introduce a further story about the path leading to reconciliation. They are symbolized by friendly gestures exchanged by politicians and signed agreements illustrated in the pictures. Against this background, information was placed that on 12th November 1989 in Krzyżowa in Silesia, the Polish Prime Minister Tadeusz Mazowiecki met with German Chancellor Helmut Kohl at the religious service for forgiveness. That year also brought other changes. The two illustrations symbolically show the victory of solidarity and the fall of the Berlin Wall. The inscription says that thanks to the victory of the Solidarity Trade Union, Poland gained freedom and the Germans united. At the next illustration, one learns that on 17 June 1991, the Polish-German treaty on good neighborliness was signed, which was a milestone in mutual relations. The image of laughing faces is a background for the cartouche with information that today Poles and Germans have close and friendly relations in all areas of cooperation. How can one summarize this message? Probably only that a difficult past does not have to constitute a permanent point of ignition between states and nations, and should not affect mutual relations and the possibility of cooperation. Forgiveness is difficult, but cultivating hatred we will not change anything in mutual relations for the better. Considering the aim of publishing such a comic, it can be said that it reflects the attitude of the country's government in the foreign policy. The lack of commentary, as far as the consequences of the shown events are concerned, results from the form of expression and out of necessity trivializes the information and historical background.

What is noteworthy is the fact that the Polish-German history has become an example for the Asian people, knowing European history, of how the Japanese-Korean cooperation should develop and how the complicated historical issues between the two countries should be coped with ${ }^{14}$.

There is a conflict between Japan and South Korea concerning the interpretation of historic events, which affects the mutual relations of the countries and societies ${ }^{15}$. Michael Ha has identified Poland and Germany

14 See: R. Gałaj-Dempniak, Education for peace: the role of the Peace Boat in building a basis for agreement among Asian feuding countries, w: Aspects of contemporary Asia. Security and economy, red. J. Marszałek-Kawa, Torun 2015; eadem, Takeshima Day-Dokdo Day: the Japanese- South Korean Dispute over Dokdo/Takeshima Islands in the Media, w: The Asian values discourse-myths, paradoxes, perspectives, red. J. Marszałek-Kawa, Torun 2014.

15 In a thinly-veiled swipe at Japan, South Korea's top diplomat urged the world to make utmost efforts to end "wartime sexual violence" and exhorted any offender to face 
in the article History Backs Koreas Dokdo Sovereignty in The Korean Times as an example of establishing good neighborly relations despite the difficult and blood-marked past ${ }^{16}$. He meant breaking the deadlock in the Japanese-Korean talks about the historical and educational policy of the young generation, the Japanese in particular.

The potential of every nation can undoubtedly be reflected by prominent figures representing the country among the scientific, cultural, political or economical elite of the world. An average Asian-country citizen associates Poland with Lech Wałęsa, John Paul II and Frederic Chopin. Other figures are less recognizable. Lech Wałęsa and John Paul II have appeared on the front pages of newspapers as well as in the TV news. That is why the reader has heard about the events they were involved in many times and started to associate both of them with Poland. Frederic Chopin has become famous for his music which is loved by the Japanese. In the case of the three mentioned figures we can possibly speak of supplementing the knowledge of them. All these three figures have had a comic made about them.

The publisher seems to have adopted similar principles of presenting the character: the place, the date, and the country of birth. The way leading to fame through hard work, determination to pursue goals. If the character possesses leadership features, they should be exposed creating a corresponding image. Weighty words uttered in the character's lifetime, especially those which became the prelude or motto of actions, or are considered as such. Groundbreaking events considered to be milestones which characterize man's role and people's attitude towards him.

The period of political change is undoubtedly to be associated with 2 people who appeared in the international arena: John Paul II and Lech Wałęsa. Lech Wałęsa seems to be better-known in Asia, though. The story of the comic where he appears is set in Gdańsk, Poland, and the locations of the round-table discussions. We see Lech Wałęsa as a laborer - a leader respected by his fellow workers, a very religious man,

„the dark side of its history and rectify past wrongdoings [...]”. „It requires a sound historical consciousness and heartfelt soul-searching on any past wrongdoings in order for solid peace and stability to be established between nations, $[\ldots]$.. „,The name of Japan was not used because of a diplomatic protocol that avoids referring to a certain country at the multilateral diplomatic stage, but the speech contains a stern rebuke over Japan's attitude based on its incorrect understanding of history", the official said on condition of anonymity. S. Korea presses Japan on wartime sexual slavery at U.N., 2012.09.29, „Korea Herald", http://www.koreaherald.com/view.php?ud=20120929000060\&mod=skb [dostęp: 10 III 2014].

16 Ha M., History Backs Koreas Dokdo Sovereignty, „Korea Times”, 2008.07.31 http://koreatimes.co.kr/www/news/nation/2013/03/251_28582.html [dostęp: 19 III 2016]. 
the sign of which being the portrait of Black Madonna of Częstochowa present among the protesting laborers and in the Solidarity leader's lapel, as well as the scene showing his meeting with John Paul II. Out of the characteristic events of Wałęsa's career, the author presented the scene of Wojciech Jaruzelski's television speech introducing the martial law and the round-table meeting, as well as electing Wałęsa as President of Poland in 1990. The text stresses the role played by the Solidarity's leader in changing the country's most important aspects of life. It enumerates the most important awards which he received, especially the Nobel Peace Prize (1993). We also learn that Lech Wałęsa Institute was established in 1995 whose aim was to support the concept of ethics, independence, and the country's decentralization. In addition, Andrzej Wajda, whose films were shown to the Japanese filmgoers, directed a film: Watęsa, the man of hope (Wałęsa, człowiek z nadziei). Its director, Andrzej Wajda, is known in Japan not only as a director, but also as a person who popularized the Japanese culture in Poland. The point clipping the whole comic together are Lech Wałęsa's words in which he declares that his dearest wish is that Poland uses its historic opportunity for peaceful development and that it shows the world that even most complicated situations can be resolved by dialogue, not force.

The story of John Paul II begins with an illustration showing parents with an infant born on 18 May 1920 in Wadowice, Poland (2015). This is the place where Karol Wojtyła was born. The next picture shows Karol Wojtyła now wearing papal robes, grinning and raising hands in a characteristic gesture of his. There is information which says that in 1978 a man of a non-Italian origin was elected as pope for the first time in 400 years. The next pictures show us the Holy Father's work which made it possible for him to approach men of goodwill, no matter who they were, what church they belonged to and which continent they lived on. The information says that he was the most frequently-travelling head of church, that's why he was called the pilgrim pope. A fragment of the pope's most important speech has been added to the picture of him kissing the ground dating back to his first visit to Poland, „Let your Spirit descend! Let your Spirit descend! And renew the face of the earth. The face of this land!". These words, as we read on, induced the undertaking of political change in Poland (1979). In fact, the words were said in a different place but bowing to the earth and kissing it remain the events unmistakably associated with John Paul II. The author points out that these words caused the end of communist rule in Poland and, eventually, in the whole Europe. The pope died on 2 April 2005 in Vatican City. Three million people were waiting in a line to bid him farewell in the Vatican basilica. On 27 April 2014 John Paul II was canonized. These facts show 
the greatness, uniqueness and charisma of this great Pole. His life and achievements were significant for the whole world, which was demonstrated by the crowds willing to honor him for the last time.

Frederic Chopin is commonly known and liked in Land of the Rising Sun. Many cyclical concerts are held and Chopin's pieces are performed by the best Japanese pianists ${ }^{17}$. In Japan, Polish music is promoted, among others, by the Frederic Chopin National Institute ${ }^{18}$. The campaign aiming to create Poland's brand and image has been based on the music and places associated with Chopin's work or the commemoration of Chopin in Poland. In this case Warsaw's Royal Łazienki Park, associated with the summer concerts, is used. The Japanese associate the park with Warsaw and Poland through Frederic Chopin. The knowledge of Chopin presented in the comic (2014) embraces his connection with Paris, George Sand - a writer and Chopin's friend, and the source of his income. Although Chopin remains the most popular and liked composer, the promotion of other artists is becoming more and more effective as well, the example being the work of the Japanese Society of Ignacy Jan Paderewski. During official meetings of its members not only music is important but also Ignacy Jan Paderewski's role in fighting for the independence of Poland is emphasized, as well as his contribution as a statesman, minister of foreign affairs, and the prime minister of Poland ${ }^{19}$.

The Polish Embassy and the Polish Institute were presenting last year (70th death anniversary) and this year continue (140th birth anniversary) an information campaign on the life and work of Feliks Nowowiejski, a composer, organist, educator, choirmaster, and a passionate patriot, emphasising the aspect of creating a patriotic attitude. Also, Janusz Olejniczak has been playing concerts in Japan this year, a pianist well-known for his master interpretations of Chopin's music, the 6th award winner of the 9th Chopin Contest in Warsaw. The composer of music for Roman Polanski's film The Pianist (2002) whose soundtrack earned the Gold Record status in Poland. He recorded most of the piano parts for Jerzy Antczak's film Chopin. A wish for love (Chopin. Pragnienie miłości) ${ }^{20}$.

\footnotetext{
17 Cyclical Chopin concerts are attended, for instance, by Takashi Yamamoto.

18 The National Frederic Chopin Institute, http://pl.chopin.nifc.pl/chopin/places/poland [dostęp: 19 III 2016].

19 Press conference of the Japanese Society of Ignacy Jan Paderewski, http://pl.instytutpolski.org/event/music/6442/ [dostęp: 20 III 2017].

20 A DVD with the first Roman Polański's films as director were released in Japan in 2004, The first Roman Polanski film trials, Polish site in Japan, http://klikdotsystems.jp/stronapolska/info/info2005/polanski.html [dostęp: 20 III 2017]; In 2012, in Japan there were films presented of: Wajda, Polański, Kawalerowicz, Munek and Skolimowski, Polish masters in
} 
There are two other relevant figures considering the historical connection with Japan: Józef Piłsudski (2015) and Tadeusz Romer. The information on the Embassy's website refers to Marshal Józef Piłsudski as the father of the Polish independence. Józef Piłsudski visited Tokyo during the Japanese-Russian war in $1904^{21}$. The outcome of the visit exerted positive influence on the Polish-Japanese relations in the following years. As far as forming the reader's opinion is concerned, it is crucial to note the fact that it was before the first world war that the Polish-Japanese cooperation was established. The period of forming imperial Japan and its territorial expansion of that time remains an important historical fact for the Japanese youth. It tends to be perceived in many different ways as it does not matter to everyone that it was conducted at the cost of other Asian nations. In the comic book, Piłsudski is a hero fighting against Tsarist Russia for the restoration of Poland, its territory and borders. He organizes the Legions, there is no information which world powers support him, though. In 1918 he becomes the leader of the reborn Poland. The situation is rather simplified here and there is only one enemy. The born-anew Poland, threatened by the Soviets, is saved in the battle of Warsaw, and the war ends with a peace treaty signed in 1921. The end of the Marshal's life is romantic. After his death in 1935, his body is buried in a silver coffin in the Wawel Cathedral. But the son's loving heart rested in his mother's grave in Vilnius. Stressing that Piłsudski is the creator of the Polish independence and that the restoration of the country is celebrated on 11th November is intentional in the text. Out of many speeches made by Piłsudski, those have been chosen which say that the nation which does not respect or value its past, is not to be respected in the present and has no right for the future. These are very interesting words considering the historical policy followed by Japan. The post-war order is perceived by the Japanese in the light of harm they suffered: occupation, atomic bombs, tradition and cultural property being destroyed, long-standing control of the policy exercised by the non-Japanese. Their respect for tradition expressed, among others, by worshipping the dead heroes buried in the Yasukuni temple brought Japan some

Japan, Culture.pl, http://culture.pl/pl/wydarzenie/polscy-mistrzowie-w-japonii [dostęp: 20 III 2017].

21 A. Garlicki, Józef Piłsudski 1867-1935, Warszawa 1988; W. Pobóg-Malinowski, Józef Piłsudski 1901-1908. W ogniu rewolucji, Warszawa 1935, s. 214; R. Dmowski, Polityka polska i odbudowanie państwa, Warszawa 1925, s. 46; T. Filipowicz, Piłsudski in Japan, article scans, http://www.pilsudski.org/archiwa/dokument.php?nrar=701\&nrzesp=1\&sygn=56\&handle=701.180/1901 [dostęp: 5 IV 2016]; J. Drożdżewski, A Japanese episode in Roman Dmowski's life, http://japonia-online.pl/article/287 [dostęp: 24 IV 2014]; E. Pałasz-Rutkowska, A. Romer, Historia stosunków polsko-japońskich 1904-1945, Warszawa 2009. 
political problems, suspicions of imperialistic resentment and repression against the Japanese citizens and enterprises, for example in China and South $\mathrm{Korea}^{22}$. The author of the comic, having a long-lasting connection with Japan, seems to understand the mentality of the Japanese society so well that he chooses the elements of the country's and nation's past which remain important not only for the Polish but also for the Japanese people.

The other figure from a comic is Tadeusz Romer, a long-lasting Polish ambassador in Japan. He was born, like Piłsudski, in the land now belonging to Lithuania. When the country of Poland was restored, he began his service for the country in diplomatic corps in Paris, Rome, and Lisbon. From 1937, the year when a permanent diplomatic post was established, he represented the Polish government in Japan. The outbreak of the Second World War changed the character of his mission dramatically. The number of tasks increased, especially the ones concerning the Jewish people, who were fleeing via Russia to Japan after 1939, with Japanese visas issued by consul Chiune Sugihara who was residing in Kowno. The embassy in Tokyo was closed in 1941 after the German-Russian war broke out and the Sikorski-Majski pact was signed. Romer and his wife moved to Shanghai where they were attending to the refugees' matters. In 1942,

22 K. Żakowski, Kryzys w relacjach chińsko-japońskich w zwiazku ze sporem o Wyspy Senkaku/Diaoyutai, w: Wspótczesna Azja Wschodnia. Wybrane zagadnienia, red. K. Żakowski, Łódź 2011, s. 127-140; M. Miazek, Spór o liczbę ofiar masakry nankińskiej, w: Wspótczesna, s. 141-152; T. Marciniak, Polityka historyczna Japonii wobec China, w: Wspótczesna, s. 153-160; J. Yi, Global Concerns and Hopes for Korea-Japan Relations, „Foreign Policy Journal”, 3.12.2012, http:// www.foreignpolicyjournal.com/2012/12/03/global-concerns-and-hopes-for-korea-japanrelations/\#.U0GaoSyKDIU [dostęp: 2 III 2014]; J. Nishino, S. Korean leaders must jointly look to peace and stability, „New Japanese”, 8.02.2013, https://ajw.asahi.com/article/forum/ security_and_territorial_issues/japan_south_korea/AJ201302080001 [dostęp: 8 II 2013]; P. Si-soo, Anti-hallyu voices growing in Japan, "The Korean Times", 21.02.2014, http://www.koreatimes.co.kr/www/news/culture/2014/02/386_152045.html [dostęp: 2 III 2014]; Extremely rare evidence of Nanjing Massacre filmed by US pastor in 1937, China Global Television Network, https://www.youtube.com/watch?v=MVRBPGe2k94 [dostęp: 2 III 2014]; UNESCO in deliberation on Nanjing Massacre, wartime sex slavery documents 유네스코, Arirang News, https://www.youtube.com/watch?v=1yA-wHJOmFM [dostęp: 2 III 2014]; Men Behind The Sun- Unit 731, https://www.youtube.com/watch?v=_jrifmpz7LA [dostęp: 2 III 2014]; Japanese World War II veterans recall horrors of Unit 731, New China TV, https://www.youtube. com/watch?v=Tx7loRv70y8 [dostęp: 2 III 2014]; Japan's relation with S. Korea is 'bad' - survey, „The Tokio Times”, http://www.tokyotimes.com/2013/japans-relation-with-s-korea-is-bad-survey/ [dostęp: 2 III 2014]; K. Mikyoung, Human Rights, Memory and Reconciliation: Korea-Japan Relations, „The Asia-Pacific Journal” 2013, 2, 11, http://japanfocus.org/-Mikyoung-Kim/3911\# [dostęp: 2 V 2014]; T. Morris-Suzuki, Migrants, Subjects, Citizens: Comparative Perspectives on Nationality in the Prewar Japanese Empire, "The Asia-Pacific Journal: Japan Focus" 2008, 6, 8, http://www.japanfocus.org/-Tessa-Morris_Suzuki/2862 [dostęp: 7 IV 2014]. 
Majski offered Romer a job in a very difficult post in the USSR but after the discovery of the Polish officers' graves in Katyń, which in turn led to a diplomatic crisis, he left the country. In 1943, Romer accepted the position of foreign affairs minister in Stanisław Mikołajczyk's government in exile. After the war he settled down in Canada where he worked as a lecturer at a university in Montreal until his death in 1978. In the comic there are two heroic figures cooperating with each other, the Ambassador of Poland and of Japan. Both of them saved hundreds of people, both of them were ethical and empathetic people. Thus, we have another example of a positive relation in the Polish-Japanese past. The fact of being on the opposite sides of the fence makes it even more valuable.

The story of Jan Karski is also associated with the wartime history. The comic was one of the elements of the Jan Karski Year celebration (2014). The story is the most dramatic and suggestive one when one analyses the content of illustrations. The very first scene shows an SS man behind whom one can notice the Schleswig-Holstein vessel shooting, and hordes of German soldiers carrying banners with the sign of swastika on them. Although the cartouche informs of the German and Russian troops invasion in 1939, there is no reference to the latter army. There is a fragment of The New York Times informing of Poland being invaded and the course of battles, though. The next presented scene is as dramatic as the first one. It shows a Jew wearing the Star of David who is fleeing through the fence of a concentration camp filled with human skeletons. The cartouche says that a young Polish officer, associated with the underground, risked his own life to inform the West about the mass-murder of the Jews. There is also a scene where two Jews turn to Jan Karski and ask him to inform the West about the extermination of the Jewish people conducted by Germans. The next images show executions and death being the result of famine and disease in the Warsaw ghetto. The words tell how Karski, risking his life, collected the documentation in those places and next handed it over to the governments of Great Britain and the USA. His reports terrified the recipients but they did not bring about any reaction to the genocide. In 1994, Jan Karski published a book "A secret country" (Tajne panstwo). It was only then that the story of what was happening in Poland became widely known (the underground fight, the annihilation of Poles and Jews). The book became a best-seller. It foiled the Allies' attempt to hide the uncomfortable truth. Karski has a place in the pantheon of people committed to work for the sake of other people's good.

Due to the 1050th anniversary of the Baptism of Poland, the Polish Embassy in Tokyo has prepared a special edition of a picture story of the Polish Duke Mieszko I (2016), who was a Piast dynasty representative, 
the founder of the country and the first catholic ruler baptized in $966^{23}$. It was the consequence of marrying a Czech princess Dobrawa who persuaded him to accept Christianity. Baptising the Polish duke paved the way for Poland to access the world of the western Christian culture. After the duke's death, the rule of Poland was taken over by his son, Bolesław Chrobry, who became the first Polish king. In order to celebrate the 1050th anniversary of the Baptism of Poland, the Polish National Bank issued a unique 20-złoty banknote with an image of Mieszko I and Dobrawa on it. The comic presents the most basic information and the importance of the past events is reflected by placing the image of Mieszko on the banknote.

A man from a more distant past is also Nicolaus Copernicus (2014). He is associated with Torun, but he studied in Cracow, Padua, Bologna, and Ferrara. He is presented as a broadly-educated man, even when the standards of Renaissance are to be considered. The knowledge he acquired enabled him to discover that the Sun is the centre around which the Earth revolves, which was a milestone in the history of scientific development. He is the creator of the heliocentric theory included in the work "De revolutionibus orbium coelestium" which was printed in the year of his death (1543). The author emphasized the great importance of Copernicus' contribution to the development of mankind, which placed him among world's greatest scientists using their mind and research for the good of mankind despite being persecuted for spreading theories contradictory to those officially approved.

There are two more great people honored with a comic. They are writers: Henryk Sienkiewicz and Stanisław Lem. In the case of Sienkiewicz, his most famous works are mentioned, especially "Quo vadis" (1896) and "Knights of the Teutonic Order" (Krzyżacy) (1900). The author stressed the fact that the writer was a Nobel Prize winner in literature. The minicomic was created to commemorate the writer's 170th anniversary of birth and 100th anniversary of death in 2016. The year was announced by the Polish authorities to be the year of Sienkiewicz.

Stanisław Lem was presented as a brilliant science fiction writer. His works have been translated into more than 40 languages. It has been explained that he was born in Lviv, now Ukraine. His family moved to Cracow where he took up medical studies. One of his greatest works is "Solaris", a novella written in 1961, adapted for screen three times. The author died in 2006. Also, Tadeusz Kantor, the founder of the Cricot 2 theatre and the author of the play „Umarła klasa” (The Dead Class) (1975),

23 The Polish Embassy in Tokyo, http://www.tokio.msz.gov.pl/pl/aktualnosci/komiks_o_mieszku_i___pierwszym_historycznym_i_chrzescijanskim_wladcy_polski [dostęp: 3 V 2016]. 
an avant-garde artist, was honored with a comic book for his jubilee (2015). In order to commemorate his 100th birth anniversary, the Polish Embassy in Tokyo has prepared a comic „Tadeusz Kantor - A man of art and theatre". What made Kantor unique was not only his way of perceiving the surrounding reality but also the fact that he was always present on stage among the actors during performances. He died suddenly in 1990 after his last rehearsal for the play "Dzisiaj są moje urodziny” (Today is my birthday). The world premiere of the play was in 1990. The author of the comic refers to Kantor's works as the milestones of contemporary theatre. The Japanese love the theatre, therefore, promoting the people of theatre is a good move. They may become positive calling cards of Poland, e.g. 2017 will be the year of Joseph Conrad-Korzeniowski, wellknown in Japan, due to the 160th anniversary of his birth ${ }^{24}$.

It is interesting why legends associated with the Polish cities are presented by means of comics, too. There is a comic about Gdańsk - the legend of the lions from the Gdańsk city hall (2014). Wrocław - the legend of Kluskowa Brama (the Dumpling Gate) (2013). Cracow - the legend of the Wawel Dragon (2013). Warsaw - the legend of the Warsaw Mermaid (2013). Warsaw - the legend of Wars and Sawa (2013). The legend of Lech, Czech and Rus (2013). Apart from receiving the educational value, Japanese are associated with the name and emblem of the state and an attractive, easy to remember history. The names of the cities mentioned in the comics stop being only a meaningless bundles of sounds, they become real places with their history and interesting people. That is why they are worthy learning about. Poland started promoting itself on Japanese websites. Once in a while we can come across an advert promoting a different city or region. The Japanese market requires systematic, longlasting actions in order to convince the viewer that what he or she sees in western Europe is present in Poland as well and is similarly or even more attractive. Poland is visited mostly by Japanese pensioners and quite a few young people. According to the data of the Japanese Embassy, their number may total about 60 thousand people a year. The Polish restaurant owners, hoteliers and tour guides have been preparing for a while now to deal with Japanese tourists who have specific preferences as far as the stay conditions are concerned ${ }^{25}$.

\footnotetext{
24 „Jądro ciemności” (“Heart of Darkness”, 『闇の奥』), „Lord Jim” (『ロード・ジム』), „Smuga cienia” („The Shadow Line”『陰影線 ( シャドウ・ライン )』).

25 E. Odagiri, Rozmowa z Andrzejem Kozłowskim, prezesem Polskiej Organizacji Turystycznej, http://polonia.jp/pl/wywiady/item/742-rozmowa-z-andrzejem-koz\%C5\%82owskim-pr ezesem-polskiej-organizacji-turystycznej [dostęp: 1 IV 2020]; http://www.pot.gov.pl/pot-a-organizacje-i-struktury-miedzynarodowe/ [dostęp: 6 IX 2013].
} 
The Polish Embassy in Tokyo not only tries to be the promoter of the Polish culture but also the advocate for learning about Poland, its tourist attractions, market and possibilities. A potential Japanese tourist has to get as much information as possible, materials, films, folders to persuade him or her to visit a particular place. In 2005, the Polish Tourist Organisation opened an information centre in Japan. The institution cooperates with the Economic and Trade Department of the Polish Embassy which is responsible, among others, for the promotion of tourism. It also cooperates with the organizations of the Visegrad associated countries. In order to cut the cost, they jointly invite study groups, tour operator groups and journalists from Japan. They also carry out publishing activities and they run a website. The undertaken actions have not led to the "invasion" of Asian tourists like the one to be observed in Western Europe countries. Presently, there is a small Polish diaspora, Polish scientists and students in Japan. According to the observation made by the Polish people and Polish ambassadors residing in Japan, it is necessary to broaden the knowledge of Poland among the Japanese people because they know little about it. The Polish ambassadors in Japan stress that a change in media communication and all other potential aspects of the Polish-Japanese relations must take place $^{26}$. Cultural activities must be used in favor of political, economic and tourist promotion. Poland-promoting activities in Japan include publishing books, comics, mangas, making videos popularizing the country, region, prose, films, theatre performances, organizing parties and concerts.

What is so vital about the campaigns? The fact that the Japanese, being aware of the technological underdevelopment in many aspects of the Polish economy, have to acknowledge the equivalence of the potential of the Polish society and its undeniable contribution to the world's civilization. The young generation in particular, to whom the future belongs, may change the way of thinking about the inhabitants of this part of Europe. They may be encouraged to learn personally about the world the heroes from the comics were fighting for. For the Japanese, as well as for the Polish, tradition and history are of great importance.

(translated by Małgorzata Mika)

26 F. Tsugami, Wywiad z Ambasadorem RP w Tokio Cyrylem Kozaczewskim, http://polonia.jp/pl/wywiady/item/1109-zaciesnianie-relacji-polsko-japonskich-w-cieniu-fukushimy, [dostęp: 5 IX 2013]. „Excellent Poland - Rising Polska” has also been published, the first complex publication about Poland in Japanese . It is the result of the cooperation of the Embassy (the Department of Promotion, Trade and Investment), the Polish Institute in Tokyo and the Polish Tourist Organisation and the Japanese partner Silver Stone JP Co., Ltd., supported by Polish and Japanese sponsors. The „Hot Poland” bulletin was also created, aimed at introducing broadly understood Polish culture and science to the Japanese. 


\section{REFERENCES (BIBLIOGRAFIA)}

\section{Studies (Opracowania)}

Dmowski R., Polityka polska i odbudowanie państwa, Warszawa 1926.

Gałaj-Dempniak R., Education for peace: the role of the Peace Boat in building a basis for agreement among Asian feuding countries, w: Aspects of contemporary Asia. Security and economy, red. J. Marszałek-Kawa, Torun 2015.

Gałaj-Dempniak R., Obraz stosunków polsko-japońskich w prasie japońskiej i na japońskich stronach internetowych, w: Dylematy polityki zagranicznej Polski na poczatku XXI w., red.

K. Czornik, M. Lakomy, M. Stolarczyk, Katowice 2014.

Gałaj-Dempniak R., Takeshima Day-Dokdo Day: the Japanese-South Korean Dispute over Dokdo/ Takeshima Islands in the Media, w: The Asian values discourse-myths, paradoxes, perspectives, red. J. Marszałek-Kawa, Torun 2014.

Gałaj-Dempniak R., Pozorski M., Stosunki polsko-japońskie w latach 2014-2016, w: Stosunki Polski z mocarstwami w drugiej dekadzie XXI wieku, red. K. Czornik, M. Lakomy, M. Stolarczyk, Katowice 2016.

Garlicki A., Józef Piłsudski 1867-1935, Warszawa 1988.

Marciniak T., Polityka historyczna Japonii wobec Chin, w: Wspótczesna Azja Wschodnia. Wybrane zagadnienia, red. K. Żakowski, Łódź 2011.

Miazek M., Spór o liczbę ofiar masakry nankińskiej, w: Wspótczesna Azja Wschodnia. Wybrane zagadnienia, red. K. Żakowski, Łódź 2011.

Pałasz-Rutkowska E., Romer A., Historia stosunków polsko-japońskich 1904-1945, Warszawa 2009.

Pobóg-Malinowski W., Józef Piłsudski 1901-1908. W ogniu rewolucji, Warszawa 1935.

Żakowski K., Kryzys w relacjach chińsko-japońskich w zwiazku ze sporem o wyspy Senkaku/Diaoyutai, w: Wspótczesna Azja Wschodnia. Wybrane zagadnienia, red. K. Żakowski, Łódź 2011.

\section{Web sources (Źródła internetowe)}

Chmielewski Ł., Komiks promuje Polskę w Japonii (A comic promotes Poland in Japan), Culture. pl, http://culture.pl/pl/tag/rafal-gosieniecki [dostęp: 6 VI 2014].

Drożdżewski J., Japoński epizod w życiu Romana Dmowskiego (A Japanese episode in Roman Dmowski's life), http://japonia-online.pl/article/287 [dostęp: 24 IV 2014].

Extremely rare evidence of Nanjing Massacre filmed by US pastor in 1937; China Global Television Network, https://www.youtube.com/watch?v=MVRBPGe2k94 [dostęp: 2 III 2014].

Facebook, http://www.lazienki-krolewskie.pl/pl/aktualnosci/ksiezna-takamado-z-wizytaw-lazienkach-krolewskich [dostęp: 10 V 2016].

Filipowicz T., Piłsudski w Japonii, skany artykułu (Pisudski in Japan, article scans), http:// www.pilsudski.org/archiwa/dokument.php?nrar=701\&nrzesp=1\&sygn=56\&handle=701.180/1901 [dostęp: 3 V 2016].

Gildia.pl, http://www.komiks.gildia.pl/tworcy/rafal_gosieniecki [dostęp: 6 VI 2016].

Ha M., History Backs Koreas Dokdo Sovereignty, „The Korea Times”, http://koreatimes.co.kr/ www/news/nation/2013/03/251_28582.html [dostęp: 19 III 2016].

http://www.mofa.go.jp/erp/c_see/pl/page4e_000197.html [dostęp: 10 V 2016].

http://www.pot.gov.pl/pot-a-organizacje-i-struktury-miedzynarodowe/ [dostęp: 6 IX 2013].

Japan's relation with $S$. Korea is 'bad' - survey, "The Tokio Times", http://www.tokyotimes. com/2013/japans-relation-with-s-korea-is-bad-survey/ [dostęp: 2 III 2014].

Japanese World War II veterans recall horrors of Unit 731; New China TV, https://www.youtube.com/watch?v=Tx7loRv70y8 [dostęp: 2 III 2014]. 
Yi J., Global Concerns and Hopes for Korea-Japan Relations, „Foreign Policy Journal”, 3.12.2012, http://www.foreignpolicyjournal.com/2012/12/03/global-concerns-and-hopes-forkorea-japan-relations/\#.U0GaoSyKDIU [dostęp: 2 III 2014].

KLe, RC, Wulgarny komiks o Chopinie to "przypadek" (The vulgar comic about Chopin is an "accident"), Onet wiadomości, http://wiadomosci.onet.pl/kraj/wulgarny-komiks-ochopinie-to-przypadek/b2xxr [dostęp: 22 II 2011].

Men Behind The Sun- Unit 731, https://www.youtube.com/watch?v=_jrifmpz7LA [dostęp: 2 III 2014].

Mikyoung K., Human Rights, Memory and Reconciliation: Korea-Japan Relations, „The Asia-Pacific Journal" 2013, 2, 11, http://japanfocus.org/-Mikyoung-Kim/3911\# [dostęp: 2 V 2014].

Morris-Suzuki T., Migrants, Subjects, Citizens: Comparative Perspectives on Nationality in the Prewar Japanese Empire, „The Asia-Pacific Journal: Japan Focus” 2008, 6, 8, http:// www.japanfocus.org/-Tessa-Morris_Suzuki/2862 [dostęp: 7 IV 2014].

MSZ: Komiks o Chopinie musi zostać zniszczony (The comic about Chopin must be destroyed), http://wiadomosci.gazeta.pl/wiadomosci/1,114873,9149028,MSZ_Komiks_o_Chopinie_musi_zostac_zniszczony.html [dostęp: 22 II 2011].

Muzeum Sztuki i Techniki Japońskiej Manggha w Krakowie, Szkoła Języka Japońskiego, Japonia-online, http://japonia-online.pl/article/559 [dostęp: $10 \mathrm{~V}$ 2016].

Niezwykty sukces „Solidarnych z Japonia", Polskie Radio, http://www.polskieradio.pl/9/201/ Artykul/562720,Niezwykly-sukces-Solidarnych-z-Japonia [dostęp: 20 IV 2016].

Nishino J., S. Korean leaders must jointly look to peace and stability, „New Japanese”, 8.02.2013, https://ajw.asahi.com/article/forum/security_and_territorial_issues/japan_south_korea/AJ201302080001 [dostęp: 8 II 2013].

Odagiri E., Rozmowa z Andrzejem Kozłowskim, prezesem Polskiej Organizacji Turystycznej, http://polonia.jp/pl/wywiady/item/742-rozmowa-z-andrzejem-koz\%C5\%82owskimprezesem-polskiej-organizacji-turystycznej [dostęp: 1 IV 2020].

Polska-brama japońskich inwestycji, Invest in Poland, http://www.paiz.gov.pl/20150227/polska_brama_japonskich_inwestycji [dostęp: 27 VI 2016].

Polsko-japońskie wiadomości gospodarcze, Jetro Poland, https://www.jetro.go.jp/poland/wiadomosci/gospodarcze.html [dostęp: 26 II 2016].

Pomoc dla Japonii, News, http://www.news365.pl/index.php?option=com_content\&view=a rticle\&id=175:pomoc-dla-japonii\&catid=43:ogoszenia\&Itemid=37 [dostęp: 6 VI 2016].

Poplar, http://www.poplar.co.jp/shop/shosai.php?shosekicode=60360020 [dostęp: 6 VI 2016].

Porozumienie w sprawie TPP oraz drugi etap abenomiki - polityki gospodarczej premiera Shinzo Abe, Makoto Yamanaka, Ambasador Japonii w Polsce, http://www.pl.emb-japan.go.jp/ ambasada/documents/letter13.html [dostęp: 27 VI 2016].

Press conference of the Japanese Society of Ignacy Jan Paderwski, http://pl.instytut-polski.org/ event/music/6442/ [dostęp: 20 III 2017].

Prezydent $i$ polski biznes $z$ wizyta $w$ Japonii, Invest in Poland, http://www.paiz.gov. pl/20150226/prezydent_i_polski_biznes_z_wizyta_w_japonii [dostęp: 26 II 2016].

Sikora T., Komiks o Chopinie na przemiat, czyli kto "nie skumat”, Niemcy-online, http://www. niemcy-online.pl/inne/audio-video/komiks-o-chopinie-na-przemial-czyli-kto-nieskumal-558 [dostęp: 24 II 2011].

Si-soo P., Anti-hallyu voices growing in Japan, „The Korean Times”, 21.02.2014, http://www. koreatimes.co.kr/www/news/culture/2014/02/386_152045.html [dostęp: 2 III 2014].

S. Korea presses Japan on wartime sexual slavery at U.N., http://nwww.koreaherald.com/ view.php?ud=20120929000060 [dostęp: 10 III 2014]. 
The Polish Embassy in Tokyo, http://www.tokio.msz.gov.pl/pl/aktualnosci/komiks_o_ mieszku_i__pierwszym_historycznym_i_chrzescijanskim_wladcy_polski [dostęp: 5 IV 2016].

Tsugami F., Wywiad z Ambasadorem RP w Tokio Cyrylem Kozaczewskim (An interview with the Polish Ambassador in Tokyo Cyryl Kozaczewski), http://polonia.jp/pl/wywiady/ item/1109-zaciesnianie-relacji-polsko-japonskich-w-cieniu-fukushimy [dostęp: 5 IX 2013].

UNESCO in deliberation on Nanjing Massacre, wartime sex slavery documents 유네스코, ARIRANG NEWS, https://www.youtube.com/watch?v=1yA-wHJOmFM [dostęp: 2 III 2014].

\section{ABOUT THE AUTHOR}

Renata Bożena Gałaj-Dempniak - dr hab., pracownik naukowy Instytutu Historycznego Uniwersytetu Szczecińskiego, autorka kilkudziesięciu prac naukowych m.in. Zycie codzienne szlachty polskiej w epoce sarmatyzmu (Szczecin 1998); Propaganda wojenna $w$ Rzeczypospolitej w świetle literatury staropolskiej (Szczecin 2008); Strach, przesad, zabobony $w$ mentalności szlachty polskiej w świetle pamiętników XVII-XVIII w., w: Tantum possumus, Quantum scimus (Szczecin 2012); Takeshima Day-Dokdo Day. The Japanese-South Korean Dispute over Dokdo/Takeshima Islands in the Media, w: The Asian values discourse-myths, paradoxes, perspectives (Torun 2014); Education for peace: the role of the Peace Boat in building a basis for agreement among Asian feuding countries, w: Aspects of contemporary Asia. Security and economy, red. J. Marszałek-Kawa (Toruń 2015); Fukushima - problem skażonej żywności, w: Międzynarodowe implikacje awarii elektrowni atomowej w Fukushimie. Wybrane aspekty problemu, red. R. Gałaj-Dempniak (Szczecin 2015); Japoński Czerwony Krzyż w walce ze skutkami Fukushimy, w: Japonia widziana z polskiej perspektywy, red. J. Marszałek-Kawa (Toruń 2016). 